Available online at

INSECTA

Integrative Science Education and Teaching Activity Journal

Journal homepage : https://jurnal.iainponorogo.ac.id/index.php/insecta

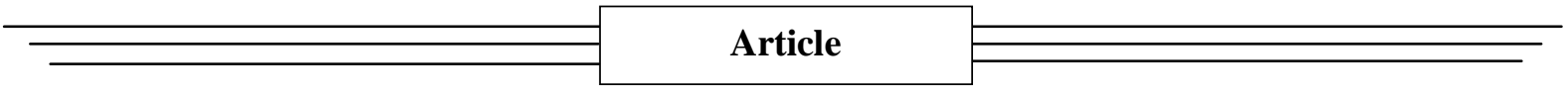

\title{
Analysis of Science Literacy Ability of Junior High School Students Based on Programme for International Student Assessement (PISA)
}

\author{
Latifatus Sholikah $^{1 *}$, Faninda Novika Pertiwi ${ }^{2}$ \\ ${ }^{1,2}$ Tadris Ilmu Pengetahuan Alam Department, IAIN Ponorogo, Indonesia.
}

*e-mail: latifatussholikah25@gmail.com

\section{Article Info}

Article history:

Received: March 26, 2021

Accepted: April, 282021

Published: May 31, 2021

\section{Keywords:}

Science Literacy

PISA

21st Century

\begin{abstract}
This study aims to analyze the scientific literacy skills of students at MTs N 2 Ponorogo. Science literacy is individual ability to apply the principles of science in everyday life, especially in making decisions and get involved in science issues. This research is fundamental in determining students' scientific literacy skills which are an important ability in facing the challenges of the 21 st century. The research method used is qualitative with a naturalistic design. The subjects of this study were 9 students using techniques purpossive sampling. The data collection techniques used were tests and interviews. In addition, science teachers also play a role as supporting subjects. The test in this study used a scientific literacy test adapted from PISA. The test is only on the aspect of scientific competence with indicators explaining scientific phenomena, evaluating and designing inquiry approaches, interpreting data and evidence scientifically. Meanwhile, interviews were conducted in an unstructured manner. Data analysis used Miles and Huberman's model, namely data reduction, data presentation, conclusion and verification. The results showed that students had an average scientific literacy ability of 76.85 in the "good" category"
\end{abstract}

\section{INTRODUCTION}

Education is one of the basic needs for every individual (Hidayati et al.,2021). Education also plays an important role in creating new generations of a nation, especially in facing the challenges of the 21 st century. The existence of education is expected to be able to produce individuals who are literate towards science and technology (Azrai et al., 2020). This technology has become the hallmark of the 21 st century. The 21 st century is indeed different from the previous century. The 21st century makes the world grow faster with technology. The relationship between countries and other countries is also getting closer so that there is a change in the way of life. The changes that occur are of course inseparable from development technology. This development requires people to be able to compete and adapt by improving the quality of human resources (Pertiwi et al., 2018). Each individual is expected to be able to understand technology and be wise in using it to balance the development of science and 
technology (Pertiwi et al., 2018). Wise in use is realized by using technology for the learning process, facilitating human activities and making new innovations. Technological developments that occur are basically carried out to improve the quality of life and welfare of modern society. Therefore, every individual needs to be equipped with the ability to use technology and make decisions in everyday life because this is related to the role of each individual in society and carrying on life.

One of the signs of the 21st Century is the occurrence of a comprehensive transformation that starts from an agrarian society to an industrial society and then to a knowledge society (Soh, Arsyad \& Osman in Pratiwi et al., 2019). The development of the 21 st century is also marked by the progress and demands of the times. Progress has occurred in various aspects of life, especially regarding technology. This can be seen from the existence of technology that has begun to replace human resources, so that the skills that individuals now have must develop and are not like the skills of the past (Pratiwi et al., 2019). In addition, these skills are also given to students while still at school. The main skills that students must have in the face of the 21st century are learning and innovation skills, mastering media and information, and life and career skills (Abidin in Yuliati, 2017)First, learning and innovation skills, which means that students have skills in solving problems, communicating, collaborating, thinking creatively and innovating. Second, mastering the media and information means that students have skills in using information media and technology in everyday life. Furthermore, life and career skills mean that students have skills in adaptation, independence, flexibility, initiative. socializing, productive and responsible (Yuliati, 2017). These three skills are made into a scheme with the name rainbow 21st century knowledge skills.21st century knowledge-skills rainbow (Trilling and Fadel in Pratiwi et al., 2019). The main goal of education in the 21 st century is to prioritize paradigmlearning namely learning to think logically and rationally, learning to solve problems, be independent, character building, and being tolerant and participating (Yuliati, 2017).

Educational policy trends in the 21 st century are oriented towards scientific literacy skills in science education as transferable outcome (Fives in Pujiati, 2019)Science Report Forum 2008 also stated that one of the important issues in science education is scientific literacy which aims to create a science-literate young generation (Fesham in Narut \& Supradi, 2019). Individuals who are "literate" in science will have the ability to apply scientific concepts, scientific processes, scientific attitudes and scientific values in making decisions and interacting with other people and their environment. In addition, it is also able to understand the correlation between being able to properly understand the interrelation between science, technology and society in the context of world development, including state and economic development (National Teacher Association in Dwiyanti \& Rahayuni, 2019). Quality science education certainly has an impact on the development of a country. Science education also directs students to carry out a deep learning process (Bagasta et al., 2018). This learning will train students in constructing their own knowledge (Wulandari \& Sholihin, 2016). This is because in the deep learning process students will do a thinking process and find information from what is being learned. Students who have the ability to understand scientific facts, the relationship between science, technology, technology and society in the context of world development, including state and economic development (National Teacher Association in Dwiyanti \& Rahayuni, 2019). Quality science education certainly has an impact on the development of a country. Science education also directs students to carry out a deep learning process (Bagasta et al., 2018). This learning will train students in constructing their own knowledge (Wulandari \& Sholihin, 2016). This is because in the deep learning process students will do a thinking process and find information from what is being learned. Students who have the ability to understand scientific facts, the relationship between science, 
technology and society, and being able to implement their knowledge in solving problems in real life is called a scientific literacy society (Bond in Pratiwi et al., 2019). Scientific literacy is a basic skill that is important for every society. In accordance with the World Economic Forum in 2015 regarding the determination of basic skills, namely literacy in literacy, numeracy, digital literacy, financial literacy and cultural literacy and citizenship (Kemendikbud in Pratiwi et al., 2019).

The topic of scientific literacy is interesting to discuss, especially regarding the objectives of science education in schools (Pujiati, 2019). Scientific literacy has also become a term that is widely used as an important ability that every citizen in modern society must have (Hidayah et al., 2019). The first person to use the term scientific literacy was Paul de Hart Hurt from Stanford University who stated that scientific literacy means understanding science and applying it in people's lives (De Boer in Dwiyanti \& Rahayuni, 2019). Scientific literacy comes from the Latin language, namelyliteratus means letters, literate letters or educated and scientia which means having knowledge. Literally literacy comes from the wordliteracy which mean literate literacy or literacy movement (Echols \& Shadily in Pratiwi et al., 2019). Scientific literacy is a knowledge and understanding of scientific concepts and processes that individuals use in making decisions and participating in the fields of state, culture and economy (Holbrook \& Rannikmae, 2007).

According to AAAS (American Association for the Advancement of Science) with "Project 2061", scientific literacy as the capacity to use scientific knowledge, identify questions and draw evidence-based conclusions in order to understand and help make decisions about the world and human interactions with the environment (Narut \& Supradi, 2019). Meanwhile, PISA (Program for International Student Assessment) stated that scientific literacy is the ability of individuals to engage with problems related to science by using scientific ideas, as reflective citizens (OECD, 2019). Science literate people are willing to engage in reasoned discourse about science and technology which requires the ability to explain phenomena scientifically, evaluate and design scientific inquiry, and interpret data and evidence scientifically (OECD, 2019). Scientific literacy does not only focus on understanding scientific concepts but on the ability of individuals to make decisions and participate in social life using the principles of science. PISA (Program for International Student Assessment) assess the characteristics of students' science as a scientific investigation, awareness that science and technology form a material, intellectual and cultural environment, and participate in science issues (Dwiyanti \& Rahayuni, 2019). Given the importance of scientific literacy, efforts to educate people to have scientific literacy is the main goal in any science education reform (De Boer in (Pratiwi et al., 2019).

OECD (Organization for Economic Cooperation and Development) is an international organization that focuses on the development of the world of international education. 1997, the OECD periodically conducts the International Student Assessment Program or Program for International Student Assessment (PISA) every three years (Bagasta et al., 2018). PISA aims to evaluate the results of the education system related to the learning achievement of students. In addition, PISA is carried out to help the government not only understand but also increase the effectiveness of the education system (Narut \& Supradi, 2019). PISA findings were also used to: (a) compare the reading, math and science literacy of one country's students with other participating countries; and (b) understand the strengths and weaknesses of each country's education system (Thomson \& De Bortoli, in (Ekohariadi, 2009). One of the assessments carried out by PISA is scientific literacy. Indonesia is one of the countries participating in the assessment. However, the results obtained are still not satisfactory. The results of the PISA scientific literacy assessment tend to be far from the standards set, even from year to year Indonesia has also experienced a decline. 
Based on PISA data (Program for International Student Assessment) The scientific literacy skills of Indonesian students are also still below the average when compared to international average scores and in general are at the lowest measurement stage of PISA (Toharudin in Yuliati, 2017). Indonesia's PISA ranking in 2000 was ranked 38 out of 41 countries with a score of 393. In 2003 it was ranked 38th out of 40 countries with a score of 395. In 2006 it was ranked 50th out of 57 countries with a score of 393. In 2009 it was ranked 60th out of 65 countries with a score of 383 . In 2012 from position 54 to position 64 out of 65 countries with a score of 382. In 2015 it was ranked 69 out of 76 countries with a score of 403. Finally, in 2018 Indonesia was ranked 62 out of 71 countries with a score of 389 (Narut \& Supradi, 2019). This shows that the scores of Indonesian students on scientific literacy skills are still far below the international standard scores set by the OECD institution (Yuliati, 2017). Indonesia's average score, which is still relatively low, also shows that students in Indonesia are largely unable to analyze and apply concepts to solve a problem. Students are very good at memorizing, but are still less able to use the knowledge they have. The phenomenon that occurs is that the willingness of students to read and write is still lacking (Hasasiyah et al., 2020). Indonesia's average score, which is still relatively low, also shows that students in Indonesia are largely unable to analyze and apply concepts to solve a problem. Students are very good at memorizing, but are still less able to use the knowledge they have. The phenomenon that occurs is that the willingness of students to read and write is still lacking (Hasasiyah et al., 2020).

The low mastery of scientific literacy is caused by teachers who do not familiarize themselves with the learning process by supporting students to develop scientific literacy (Anjasari in Sujudi et al., 2020). Another factor that causes the low scientific literacy of Indonesian students based on the PISA assessment is that students have not been trained in solving questions with characteristics such as questions on PISA. In fact, to improve scientific literacy, teachers also need evaluation tools based on scientific literacy. Teachers often ignore scientific literacy-based evaluation tools because they don't understand how to make these evaluation tools (Fraenkel in Huryah et al., 2017). In addition, other factors such as background, interests, intensity of learning, Previous research has discussed the importance of scientific literacy in students, including Rahayu's research which states that students with underdeveloped literacy skills can solve problems in simple and frequent situations, while those with more developed literacy abilities are able to solve new problems in complex situations (Saija, 2019). This shows that scientific literacy skills can affect students in solving problems. Students' scientific literacy skills can be known by doingassessmentt or appraisal. Assessment in science learning activities is needed to determine the scientific literacy skills of students (Muhammad et al., 2018). Evaluation of scientific literacy is used to formulate policies that can support the creation of competitive natural resources in the era of globalization, this is evidenced by OECD, 2004 that scientific literacy is indispensable in modern society (Sujudi et al., 2020). In addition, evaluation can also be used as a reference for improving the quality of education and learning that has previously been carried out.

The results of observations by researchers at the research location indicate that the laboratory room is inadequate even though the laboratory is an important room for practicum activities. During the interview process, the science teacher also added that the laboratory was still in the process of being repaired so it could not be used. Science teachers also do not understand scientific literacy and its application in science learning. Based on this background, it is necessary to conduct a study on the scientific literacy skills of students at MTs N 2 Ponorogo. Science literacy skills are focused on competency aspects. This research is expected to be a preliminary description about scientific literacy skills in making decisions about learning programs. 


\section{METHODS}

This type of research is qualitative research with a naturalistic design conducted at MTs N 2 Ponorogo in the 2020/2021 school year. The subjects of this study were 9 students of class IX $\mathrm{C}$ with the techniquepurpossive sampling on the basis of consideration of the highest score after completing the scientific literacy test. Data collection techniques in this study were tests and interviews. The research instrument used was scientific literacy questions adapted from PISA and unstructured interview guidelines. The measured scientific literacy skills are competency aspects then analyzed according to indicators. The test questions consisted of 6 essay questions then tested in class IX-C for 1 hour. This question is in accordance with the indicators of scientific competence aspects, namely explaining scientific phenomena, evaluating and designing inquiry approaches, interpreting data and evidence scientifically. The test results are then categorized into 5 namely very good, good, enough, less and very less based on the following table (Purwanto in Muhammad et al., 2018).

Table 1. Category of students' science literacy ability

\begin{tabular}{cc} 
Category & Score \\
\hline Very good & $86-100$ \\
Good & $76-85$ \\
Enough & $60-75$ \\
Less & $55-59$ \\
Very Less & $<54$ \\
\hline
\end{tabular}

After the scientific literacy test, interviews were conducted with students and teachers as supporting subjects. The data analysis was carried out using the Miles and Huberman model on the student answer sheets and the results of the interviews. Data analysis was carried out by data reduction, data presentation and drawing conclusions (Sugiyono in Faizah \& Shofiyah, 2018).

\section{RESULT AND DISCUSSION}

This research was started on Friday, March 4, 2021 by giving 6 questions of scientific literacy to students. The duration used is 1 hour to complete the science literacy test adapted from Program for International Student Assessment (PISA). The scientific literacy test was tested on 27 students of class IX-C at MT s N 2 Ponorogo. Then the 9 students with the highest score were taken. The results of students' scientific literacy abilities are as follows.

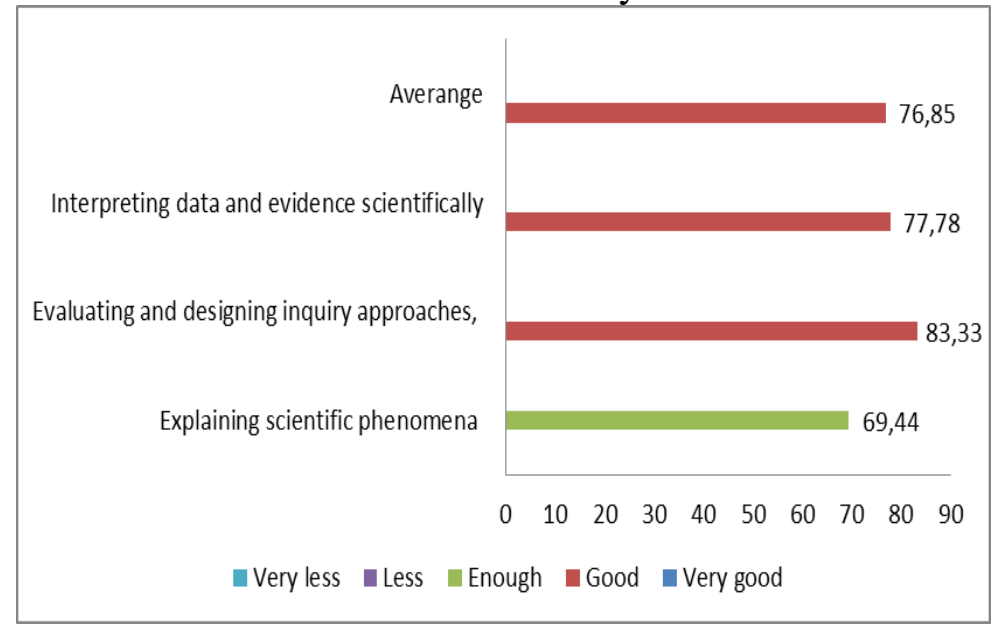

Picture 1. Science literacy test results

Based on Picture 1 it can be seen that the scientific literacy skills of students have an average score of 76.85 in the "good" category. This score is obtained from the average results of scientific literacy indicators, namely explaining scientific phenomena, evaluating and designing inquiry approaches and interpreting scientific data and evidence. Overall there were 2 students with an average score of 96.7 in the "very good" category, 2 students with an 
average score of 83.33 in the "good" category, 4 students with an average score of 66,67 and 75 in the "enough" category. "And 1 student in the" very less "category. The indicator with the highest average score is evaluating and designing an inquiry approach, namely 83, 33 categorized "good" indicates that students have been good at evaluating or conducting research using inquiry or scientific approaches. Then the indicator interprets the data and evidence scientifically, namely 77.78 with the "good" category, indicating that students both interpret data in graphical form into words and into other forms and the indicator explains scientific phenomena, namely 69.44 with the category "enough "Shows that students are sufficient in explaining a scientific phenomenon.

On indicators explaining scientific phenomena, students are expected to be able to explain, connect and predict a particular case (Novili et al., 2017). Overall the average score of students in this indicator is 69.44 in the "enough" category. These results indicate that students are quite capable of explaining scientific phenomena but not optimally. Less optimal scientific literacy skills of students are certainly caused by several factors that affect the achievement of scientific literacy skills (Wulandari \& Sholihin, 2016). The indicator explaining this scientific phenomenon is done by giving students questions about scientific literacy tests regarding the phenomenon of bird migration. Students are given pictures and scientific texts as an introduction to understanding this phenomenon. Then students are asked to predict factors that can cause inaccurate calculations of migratory birds. One of the results of the students' answers is as follows.

$$
\begin{aligned}
& \text { Ada beberapa faktor yang membuat perhitangn relawan tdk } \\
& \text { akurat, seperti jika burang yang bermigrasi melawati ja- } \\
& \text { lur / keluar jalur, migrasii ini biasanya disebut mig ras. } \\
& \text { Vagran }
\end{aligned}
$$

Picture 2. Results of students' answers

Based on Picture 2, it can be seen that students make predictions about the possibility of calculating migratory birds inaccurate, one of which is the migration of birds carried out in a different path or out of the previous route. Students also provide a scientific term for this, namely "Vagrant Migration". This answer shows that students have been able to predict one of the factors that causes the inaccurate calculation of migratory birds, namely migration to a different path. In addition, the emergence of a scientific term regarding "Vagrant Migration" also shows that students have curiosity so that they are active in seeking information about other scientific matters through books, the internet or other learning sources. In line with what Muhammad stated that curiosity will make students try to find, find, and conclude natural problems that students find in everyday life (Muhammad et al., 2018). Learning that is able to raise students 'curiosity regarding the topic and encourage students' enthusiasm to solve the problems presented by the teacher is considered capable of building science process skills which are part of the aspects of scientific literacy competencies (Wulandari \& Sholihin, 2016). Curiosity will make students continue to find out what they don't know. By finding out students will get a lot of information, new knowledge and add to the insight students have (Silmi \& Kusmarni, 2017).

Seeing that this indicator is in the "enough" category, of course, a strategy is needed to improve it. The strategy that can be done is to use the right method at the time science learning. One of them is approachscientific by making observations, seeking information and conducting experiments. In line with Safitri's research results which state that science learning applies an approachscientific can improve students' scientific literacy skills (Narut \& Supradi, 2019). This scientific approach can be done by carrying out practicum activities in 
the laboratory. However, laboratory facilities in several schools are still inadequate. This was also stated by the Science Teacher IX-C as follows.

"....Practicum is often yes but it is constrained by the laboratory room. The room is inadequate so that the teacher who will do the practicum learning can take the laboratory equipment to bring it to class"

Based on the results of the interview, it can be seen that the science teacher has made an effort to carry out practicum activities but is constrained by inadequate space. However, the solution is carried out by bringing practicum tools in class and carrying out practicum activities in class. Even though the practicum can be carried out, the tools that are carried are certainly limited so that the practicum activities will be less than optimal.

On indicators of evaluating and designing an inquiry approach, students are expected to be able to evaluate and carry out scientific investigations in a particular case (Novili et al., 2017). Overall the average score of students in this indicator is 83.33 in the "good" category. These results indicate that students are good at evaluating and designing inquiry approaches. The indicator of evaluating and designing an inquiry approach is carried out by giving students a scientific literacy test regarding the case of the phenomenon of the collapse of the bee colony. Then the question is related to the bird population. The existence of a case, of course, students must know the variables related to these two things and provide an explanation. One of the results of the students' answers is as follows

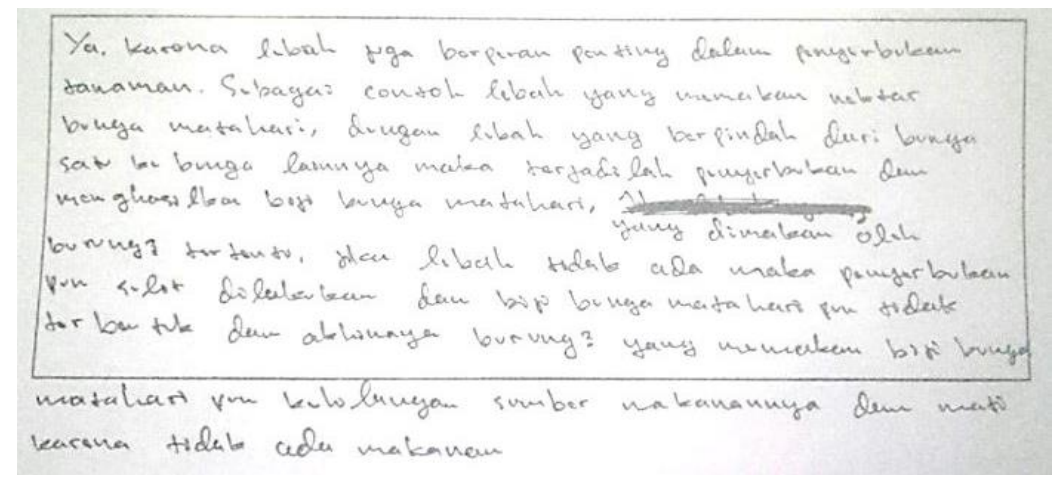

Picture 3. Results of students' answers

Based on Picture 3, it can be seen that students are able to know the variables related to the relationship between the collapse of the bee colony and the bird population, namely the existence of "pollination". Students also explained that bees eat nectar, while birds eat seeds on sunflowers. Bees also play a role in the pollination process which later produces seeds. If the bee dies (bee colony phenomenon), it will have an impact on the bird population because the seeds will decrease so that the bird is short of food. Some students still answer "No" because they focus on the text about bee colonies and do not know whether it is related to bird populations. Indicators evaluating and designing an inkuri approach do need deep understanding and a scientific or inquiry approach such as finding related variables, things that must be measured and what actions must be taken so that the data obtained is accurate (Awara, 2019). This can be trained in the science learning process.

One of the science lessons that support this indicator is project-based learning or $\mathrm{PjBl}$ which focuses on project development. In line with Raehanah's research which states that PjBL learning can affect students' scientific literacy skills as seen during the project creation process and presenting projects that have been made (Raehanah et al., 2020). The PjBL learning model also trains the skills and performance of students who have learned concepts and theories in everyday life to obtain new discoveries (Rahmawati, 2020). This certainly supports the indicators of evaluating and designing an inquiry approach in conducting investigations and project-based learning activities. 
"....The material that makes the product is for example biotechnology. Usually children make conventional biotechnology applications such as tempe, tape, etc. In addition, the children also made plant breeding products and presented them to the class"

Based on the results of the interview, it can be seen that the science teacher has carried out project-based learning or Project Based Learning $(\mathrm{PjBL})$ as in the material of biotechnology and plant propagation. Learning activities are carried out by making biotechnology products such as tempeh and practicing plant breeding such as grafting. After the product is made, it is taken to school and presented. The application of PjBL in learning certainly makes students more trained in scientifically designing products and evaluating things related to these products.

On indicators of interpreting data and evidence scientifically, students are expected to be able to analyze, interpret data and make conclusions from certain cases (Novili et al., 2017). Overall the average score of students in this indicator is 77.78 in the "good" category. These results indicate that students are good at interpreting data and scientific evidence. Indicators interpret data and evidence scientifically by giving students scientific literacy questions about the topic storage $\mathrm{CO} 2$. Students are given graphs regarding carbon storage and scientific texts then students are asked to interpret the data on the graph. As for one of the results of the students' answers is as follows.

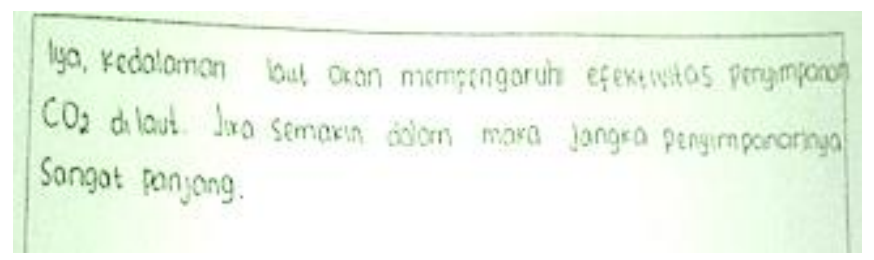

Picture 4. Results of students' answers

Based on Picture 4 it can be seen that students have interpreted it data on the graph by finding two main variables, namely sea depth and effectiveness storage $\mathrm{CO} 2$. This is also explained again in the next sentence states that the deeper (the depth of the sea to store CO2) hence the storage term is very long or more effective. On indicators interpret data and evidence scientifically, students will always be asked to change one form of representation to another (Novili et al., 2017). For example, in the form of graphics to the form of words or words to the form of tables or pictures. In line with Millar, who stated that the characteristic of scientific literacy is when students ask questions, discuss, make observations, analyze data and read scientifically based texts (Millar, 2006). Interpreting graphs is not easy because students must have other abilities. As stated by Bunawan, the use of graphics in problem processing or interpretation requires several abilities such as being able to visualize the solution to a problem, summarize data, interpret the relationship between various variables, make predictions and draw conclusions (Bunawan et al., 2015).

In this indicator, 5 out of 9 students have been able to interpret the data on the chart well even though 4 of them are still not. This is of course influenced by various factors, one of which is the practice of solving questions in the form of graphs, tables or pictures in the learning evaluation. The following are the results of the interview with the science teacher.

"....If the online evaluation uses the CBT Computer Based Test). Face to face sometimes uses a quiz, pre-test or post-test. Sometimes also collaborate so you don't get bored. Usually at the end of the chapter there is also a test"

Based on the results of the interview, it can be seen that the science teacher habitually exercises questions regularly, especially at the end of the subject matter chapter and during daily learning by doing quizzes, pre-test or post-test. Apart from being a form of evaluation, this is also done to train students in working on questions in a certain form. 


\section{CONCLUSION}

Based on the research that has been done, it can show that the literacy skills of students in the competency aspects of the highest average score are on scientific indicators and the inquiry approach approach, while the lowest is on indicators of explaining scientific phenomena. Overall, students' scientific literacy skills have an average score of 76.85 with the "good" category, indicators that explain scientific phenomena still need to be improved, especially in science learning with a scientific approach.

\section{REFERENCES}

Awara, N. (2019). Analisis Kemampuan Literasi Sains Siswa Kelas X MIA MAN 2 Payakumbuh Pada Pembelajaran Biologi Berdasarkan PISA 2015. Skripsi. IAIN Batusangkar.

Azrai, E. P., Suryanda, A., Wulaningsih, R. D., \& Sumiyati, U. K. (2020). Kemampuan Berpikir Kritis dan Literasi Sains Siswa SMA di Jakarta Timur. Edusains, 12(1), 89-97.

Bagasta, A. R., Rahmawati, D., M., D. M. F. Y., Wahyuni, I. P., \& Prayitno, B. A. (2018). Profil Kemampuan Literasi Sains Peserta Didik di Salah Satu SMA Negeri Kota Sragen. PEDAGOGIA: Jurnal Pendidikan, 7(2), 121-129.

Bunawan, W., Setiawan, A., Rusli, A., \& . N. (2015). Penilaian Pemahaman Representasi Grafik Materi Optika Geometri Menggunakan Tes Diagnostik. Jurnal Cakrawala Pendidikan, 2(2), 257-267.

Dwiyanti, A. N., \& Rahayuni, G. (2019). Analisis Sikap Literasi Sains Calon Guru SD Berdasarkan Programme for International Student Assesment (PISA). PANCAR, 3(1), 226-231.

Ekohariadi. (2009). Faktor-Faktor yang Mempengaruhi Literasi Sains Siswa Indonesia Berusia 15 Tahun. Jurnal Pendidikan Dasar, 10(1), 29-43.

Faizah, N. A., \& Shofiyah, N. (2018). Profil Literasi Sains Siswa di SMP Negeri Perkotaan dan Pedesaan. Science Education Journal (SEJ), 2(1), 25-35.

Hasasiyah, S. H., Hutomo, B. A., Subali, B., \& Marwoto, P. (2020). Analisis Kemampuan Literasi Sains Siswa SMP pada Materi Sirkulasi Darah. Jurnal Penelitian Pendidikan IPA, 6(1), 5-9.

Hidayah, N., Rusilowati, A., \& Masturi, M. (2019). Analisis Profil Kemampua Literasi Sains Siswa SMP/MTs di Kabupaten Pati. Phenomenon : Jurnal Pendidikan MIPA, 9(1), 3647.

Hidayati, A. R., Fadly, W., \& Ekapti, R. F. (2021). Jurnal Tadris IPA Indonesia Analisis Keterampilan Berpikir Kritis Siswa pada Pembelajaran IPA. Jurnal Tadris IPA Indonesia, 1(1), 34-48.

Holbrook, J., \& Rannikmae, M. (2007). The Nature of Science Education for Enhancing Scientific Literacy. International Journal of Science Education, 29(11), 1347-1362.

Huryah, F., Sumarmin, R., \& Effendi, J. (2017). Analisis Capaian Literasi Sains Biologi Siswa SMA Kelas X Sekota Padang. Jurnal Eksakta Pendidikan (JEP), 1(2), 72-79.

Millar, R. (2006). Twenty First Century Science: Insights from The Design and Implementation of a Scientific Literacy Approach in School Science. International Journal of Science Education, 28(13), 1499-1521.

Muhammad, S. N., Listiani, L., \& Adhani, A. (2018). Hubungan Antara Literasi Sains dan Rasa Ingin Tahu Siswa pada Materi Ekosistem. Natural: Jurnal Ilmiah Pendidikan IPA, 5(2), 112-116.

Narut, Y. F., \& Supradi, K. (2019). Literasi Sains Peserta Didik dalam Pembelajaran IPA di Indonesia. Jurnal Inovasi Pendidikan Dasar, 3(1), 61-69.

Novili, W. I., Utari, S., Saepuzaman, D., \& Karim, S. (2017). Penerapan Scientific Approach dalam Upaya Melatihkan Literasi Saintifik dalam Domain Kompetensi dan Domain 
Pengetahuan Siswa SMP pada Topik Kalor. Jurnal Penelitian Pembelajaran Fisika, 8(1), $57-63$.

OECD. (2019). "PISA 2018 Science Framework", in PISA 2018 Assessment and Analytical Framework. Http://Www.Oecd.Org/, 97-118.

Pertiwi, U. D., Atanti, R. D., \& Ismawati, R. (2018). Pentingnya Literasi Sains pada Pembelajaran IPA SMP Abad 21. Indonesian Journal of Natural Science Education (IJNSE), 1(1), 24-29.

Pratiwi, S. N., Cari, C., \& Aminah, N. S. (2019). Pembelajaran IPA Abad 21 dengan Literasi Sains Siswa. Jurnal Materi Dan Pembelajaran Fisika (JMPF), 9, 34-42.

Pujiati, A. (2019). Peningkatan Literasi Sains dengan Pembelajaran STEM Di Era Revolusi Industri 4.0. Universitas Indraprasta PGRI Jakarta, 2(80), 547-554.

Raehanah, Khatimah, H., \& Suhirman. (2020). Pengaruh Model Pembelajaran Project Based Learning terhadap Kreatifitas Berpikir Dan Literasi Sains Siswa SMA N 1 Gerung Tahun 2018/2019. Spin Jurnal Kimia \& Pendidikan Kimia, 2(1), 13-26.

Rahmawati, N. A. (2020). Pengaruh Model PjBL ( Project Based Learning ) Berwawasan Lingkungan terhadap Keterampilan Observasi Peserta Didik Kelas VII Reguler pada Tema Pencemaran Lingkungan di SMP N 1 Jenangan Ponorogo. Skripsi. IAIN Ponorogo.

Saija, M. (2019). Profil Kemampuan Literasi Kimia Siswa SMA Negeri 3 Ambon. Jurnal Kiprah, 7(2), 99-106.

Silmi, M., \& Kusmarni, Y. (2017). Menumbuhkan Karakter Rasa Ingin Tahu Siswa dalam Pembelajaran Sejarah Melalui Media Puzzle. FACTUM: Jurnal Sejarah dan Pendidikan Sejarah, 6(2), 230-242.

Sujudi, M. S., Idris, T., S, S., \& Handayani, P. H. (2020). Profil Kemampuan Literasi Sains Siswa SMP Islam As-Shofa Kota Pekanbaru Berdasarkan PISA. Journal of Natural Science and Integration, 3(1), 58-69.

Wulandari, N., \& Sholihin, H. (2016). Analisis Kemampuan Literasi Sains pada Aspek Pengetahuan Dan Kompetensi Sains Siswa SMP pada Materi Kalor. Edusains, 8(1), 6673.

Yuliati, Y. (2017). Literasi Sains dalam Pembelajaran IPA. Jurnal Cakrawala Pendas, 3(2), 21-28. 